\title{
Ethnobotanical investigation of spice and condiment plants used by the Taming tribe in Aceh, Indonesia
}

\author{
ZIDNI ILMAN NAVIA ${ }^{1, \vartheta}$, DITA AUDIRA ${ }^{1}$, NURUL AFIFAH ${ }^{1}$, KASANOVA TURNIP $^{1}$, NURAINI ${ }^{2}$, \\ ADI BEJO SUWARDI ${ }^{2}$ \\ ${ }^{1}$ Department of Biology, Faculty of Engineering, Universitas Samudra. Jl. Meurandeh, Langsa 24416, Aceh, Indonesia \\ Tel.: +62-641-426535, `email: navia1529@gmail.com \\ ${ }^{2}$ Department of Biology Education, Faculty of Teacher Training and Education, Universitas Samudra. Jl. Meurandeh, Langsa 24416, Aceh, Indonesia
}

Manuscript received: 11 July 2020. Revision accepted: 1 September 2020.

\begin{abstract}
Navia ZI, Audira D, Afifah N, Turnip K, Nuarini, Suwardi AB. 2020. Ethnobotanical investigation of spice and condiment plants used by the Taming tribe in Aceh, Indonesia. Biodiversitas 21: 4467-4473. Communities are inseparable from plants in meeting their daily food needs, especially plants as supplementary food. The aim of this study was to investigate of ethnobotany and economic value of spice and condiment plants used by Tamiang tribe in Aceh, Indonesia. A field survey was conducted in three sub-districts, namely Rantau, Seruwai, and Bendahara, Aceh Tamiang District involved 150 respondents (50 individuals from each sub-district) were randomly selected. A total of 31 spices and condiments plants consisting of 26 genera and 18 families was recorded in the study area. Fruits (36\%) are the most commonly used parts of plants for spices and condiments, followed by leaves (16\%), seeds (13\%), rhizome and flower (10\% respectively), bulb (6\%), and stem and bark (3\% respectively). These species were used for preserving traditional cuisines such as bubur pedas, ikan cang rebong, and anyang. Capsicum annuum $\mathrm{L}$ has high economic value. The Tamiang tribe has always preserved traditional knowledge of the use of various spices and condiment plants for traditional cuisine.
\end{abstract}

Keywords: Aceh Tamiang, biodiversity, economics, Tamiang tribe, traditional cuisine

\section{INTRODUCTION}

Spices and condiments plants are biological resources that have played an important role in human life for a long time, have been applied to the natural plant or vegetable products and mixtures of seeds in whole or ground form to enhance the flavor or aroma of food or drinks (Rathore and Shekhawat 2008; Gadegbeku et al. 2014). Approximately 400-500 species of spices are found in the world and 275 species are found in Southeast Asia (Hakim 2015). Sixtynine of spice plants were used by local communities in Aceh Jaya district (Aqilah 2017), 34 species in Banyumas (Apriliani et al. 2014), and 19 species by Kanayatn Tribe in Kalimantan (Manangka et al. 2017). Several important species, including Amomum compactum Sol. ex Maton, Cinnamomum verum J. Presl, Syzygium aromaticum (L.) Merr. \& L.M.Perry, Zingiber officinale Roscoe, Myristica fragrans Houtt., and Piper nigrum L. are important spices plants in Indonesia. In addition, condiments are a mixture of herbs and spices blended in a liquid form (Manoj et al. 2004; Kumar and Singh 2014). Spices are therefore plants or plant products that are usually added during cooking or preparation, while condiments are plants or plant products that are added to a table of prepared food (Agize 2014; Gadegbeku et al. 2014). Spices and condiments are commonly aromatic and pungent (Achinewu et al. 1995) and are mainly used for improving the color, fragrance, and taste (Bharali et al. 2017).

The Tamiang tribe is a tribe living in the Aceh Tamiang region, Aceh Province, Indonesia were used various spices and condiments plants as food, medicine, and traditional ceremonies. These species have been found either wild or cultivated in farmland or the home garden. In general, the Tamiang tribe uses different species of spices and condiments as ingredients in traditional dishes such as bubur pedas, ikan cang rebong and anyang. This food is distinctive and rich in spices, salty, and spicy and is usually served at traditional cuisine. Aqilah (2017) reported that Aceh province rich in traditional cuisine such as gule plik, $i$ bu pedah, kuah belangong, bu minyek, asam ue, pet udeng, gule boh panah, sie masak mirah, tumeh eungkot muloh, ayam tangkap, urap on peugaga, keumamah. These foods are known to be rich in spices (Arif et al. 2013). In principle, the culinary richness and uniqueness of the traditional cuisine cannot be separated from the diversity of spices plants that grow in a different habitat. Various plants are known to be rich in nutrients and bioactive compounds that are important to human health (Navia and Chikmawati 2015; Elfrida et al. 2020; Suwardi et al. 2020a), including spices and condiment plants. However, modernization and changes in consumption patterns pose a serious threat to the future existence of spices and condiments plants (Hakim et al. 2015). In addition, the loss of species in different regions is also affected by the decline in the traditional knowledge of the local community on the use of various plant species (Maheshwari et al. 2018; Suwardi et al. 2019; Navia et al. 2019a) including spices and condiments.

Ethnobotanical knowledge has a vital role to play in the management of natural resources. This knowledge was 
passed down from generation to generation (Tamin and Albain 1995). Ethnobotany studies the relationship between human beings and plants, not only their use, but also ecological, economic, social, and culture (Maheshwari et al. 2018; Suwardi et al. 2018; Supiandi et al. 2019; Mulu et al. 2020). Ethnobotany can be used as a method to record the traditional knowledge of the local communities that have used various plants to support their livelihoods (Suryadarma 2010; Navia et al. 2020; Suwardi et al. 2020b; Suwardi et al. 2020c). Given the lack of data on spice used in the traditional Aceh Tamiang people's dishes, ethnobotany studies are needed. The aim of this study was to investigate of ethnobotany and economic value of spice and condiment plants used by Tamiang Tribe in Aceh, Indonesia.

\section{MATERIALS AND METHODS}

\section{The study area}

Aceh Tamiang District od Aceh Province, Indonesia is located between $4^{\circ} 20^{\prime} 54.8^{\prime \prime} \mathrm{N}, 9^{\circ} 03^{\prime} 47.5^{\prime \prime} \mathrm{E}$. Climatic conditions in Aceh Tamiang District are tropical humid, having an average rainfall varying $353 \mathrm{~mm}-3660 \mathrm{~mm}$, and the average daily temperature of the area is $29^{\circ} \mathrm{C}$ (Central Bureau of Statistics of Aceh Tamiang District 2020). The study was conducted from March to May 2019 at Aceh Tamiang District, Aceh Province. The research sites are situated in the Rantau, Seruwai, and Bendahara subdistricts (Figure 1).

\section{Data collection}

A field survey was conducted in three sub-districts, namely Rantau, Seruwai, and Bendahara, Aceh Tamiang District. A total of 150 respondents (50 individuals from each sub-district) were randomly sampled (Table 1). The interview was conducted face to face and each interview lasted between 20 and 60 minutes. The interview used a questionnaire consisting of several pages, including plant species, vernacular names, uses, parts usage, preparation methods, economic value, and selling price.

The

samples of plants were collected along with reporting their vernacular names, the number of species, and use. The identification of plant species is carried out at the Biology Laboratory Samudra University, Aceh, Indonesia. The botanical names have been updated using The Plant List (www.theplantlist.org), Plants of the World online (http://www.plantsoftheworldonline.org), and the International Plant Name Index (www.ipni.org).

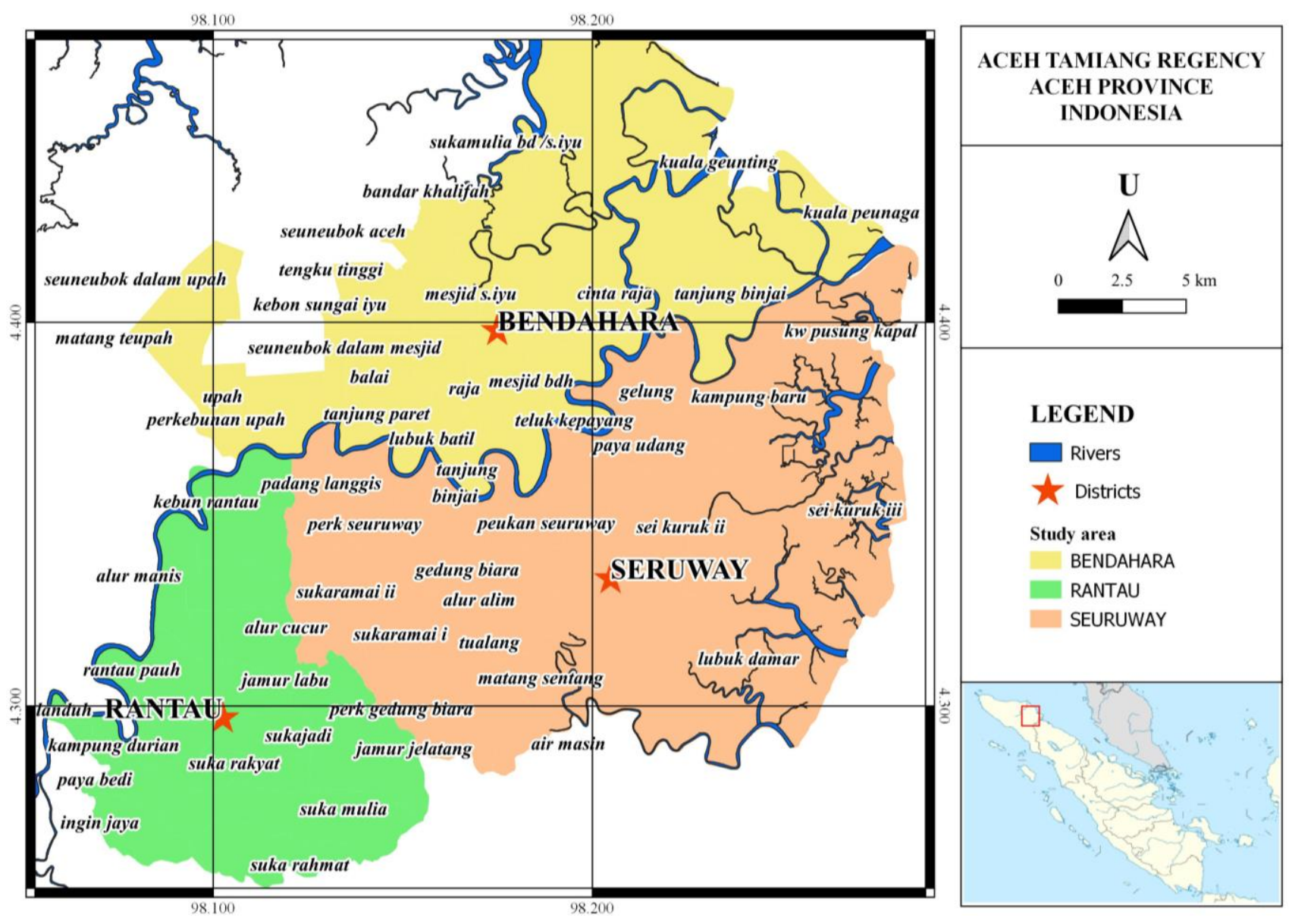

Figure 1. Map of Aceh Tamiang District, Aceh Province, Indonesia, showing the study area 
Table 1. The demographic structure of respondents

\begin{tabular}{llcc}
\hline Parameter & \multicolumn{1}{c}{ Specification } & Frequency & $\begin{array}{c}\text { Percenta } \\
\text { ge }\end{array}$ \\
\hline Gender & Female & 150 & $100 \%$ \\
Age & Youth (20-35) & 30 & $20 \%$ \\
& Adult (36-64) & 80 & $53 \%$ \\
Education & Elder (>65) & 40 & $27 \%$ \\
& None & 10 & $7 \%$ \\
& Elementary School & 9 & $6 \%$ \\
& Yunior High School & 21 & $14 \%$ \\
& Senior High School & 89 & $59 \%$ \\
& University & 21 & $14 \%$ \\
\hline
\end{tabular}

\section{Data analysis}

To compare the relative importance of each plant species, the frequency index was calculated. According to Mahwasane et al. (2013), the frequency index is a numerical expression of the percentage frequency of citation for a single plant species by informants. The following formula was used to calculate the frequency index (Madikizela et al. 2012):

$$
\mathrm{FI}=\mathrm{FC} / \mathrm{N} \times 100
$$

Where: FC is the number of informants who mentioned the use of the plant species, and $\mathrm{N}$ is the total number of informants in each area. The frequency index was high when many informants mentioned a particular plant and low when there were few reports.

\section{RESULTS AND DISCUSSION}

\section{Diversity of plants used as spice and condiments}

The results show that the plants of the study area are rich in useful, which includes a total of 31 spices and condiments plants belonging to 26 genera and 18 families (Table 2).

Allium cepa L, A. sativum L, Capsicum annuum L. are common spices and condiments plants have been found in the study area $(\mathrm{FI}=100 \%)$. However, Citrus amblycarpa (Hassk.) Ochse is rarely found in the study area (FI = $18.67 \%)$. Zingiberaceae is the dominant family found in the study area with 5 species, followed by Rutaceae (4 species), Apiaceae (3 species), and Amaryllidaceae, Lamiaceae, Myrtaceae, and Solanaceae (2 species each). Zingiberaceae is widely used by the Tamiang tribe as a spice in cooking and consistent with the reported in Northeast India (Gudade et al. 2015; Chakraborty and Chaturvedi 2015; Salam and Jamir 2016) and in West Kalimantan, Indonesia (Robi et al. 2019).

The average number of species identified by each age group of the respondent ranged from $8.5 \pm 1.21$ (20-30 years) to $44.10 \pm 0.01$ (> 65 years). In addition, the average number of species identified by each educational status of the respondent ranged from $12.8 \pm 2.01$ (University) to $33.18 \pm 2.11$ Elementary School). Some plants were recognized by all respondents include bawang mirah $(A$. cepa), bawang puteh (A. sativum), and cabe mirah (C. апnиит). On the contrary, some other species were familiar to less than $20 \%$ of the respondents. Jeruk kunci/ kesturi (C. amblycarpa) and bebuas (Premna serratifolia) are some examples for such less known species.

Relying on the ethnobotanical knowledge of the Tamiang tribe, the spice and condiment plants were divided into four categories, i.e. flavoring, seasoning, coloring, and preservation. Flavoring was the most important category among all communities followed by seasoning, preservation, and coloring (Table 3 ).

Of the total of 31 species recorded, some were used in more than one of the categories used. Accordingly, the Tamiang tribe used 31 plant species in flavoring, 26 species for seasoning, 3 species for preservation, and 2 species for coloring. This study in line with reported by Bharali et al. (2017) that flavoring was the most important category among all communities of Assam. In this study, several species have been identified which are used for various purposes. For example, the fruits of A. moluccanus are used both for flavoring and seasoning. However, the categories of use of a species may be different across sub-districts. $A$. moluccanus fruit is generally used for flavoring in Bendahara and Rantau, while this plant is used as condiments by local communities in the Seruway subdistrict. This difference can be triggered by the assumption that individuals may have different interests, perceptions, and knowledge of plants. The frequency of the use of a plant species has been reported to depend on the way people live in contexts of their social and cultural (Shrestha and Dhillion 2006; Kumar et al. 2014).

The fruits $(36 \%)$ were the most used as spice and condiment, followed by leaves (16\%), seed (13\%), rhizome and flower (10\% each), bulb (6\%), and stem and bark (3\% each). The use of leaves as spices is similar reported in Sikkim, Manipur and Tripura, and Arunachal Pradesh (Gudade et al. 2015; Salam and Jamir 2016; Chakraborty and Chaturvedi 2015; Bharali et al. 2017). The leaves were mainly used for flavoring and seasoning which may be due to the presence of active secondary metabolites than other parts of the plants (Hidayati et al. 2017; Ismail and Ahmad 2019). Tamiang tribe use of Alpinia galanga, Curcuma longa, Zingiber officinale as spices. C. longa besides being a natural coloring in cooking can also give a distinctive flavor to the cuisine, while $Z$. officinale is also used to treat coughs. Most of the Zingiberaceae family is useful as a cooking spice, medicines, spices, ornamental plants, cosmetics, and drinks (Sarangnga et al. 2013).

Cocos nucifera the most widely used by Tamiang tribe in making traditional cuisines such as bubur pedas, anyang, and ikan cang rebong. The processing method is shredded pulp to be processed into coconut, relaxed, and ground coconut. In addition, Capsicum annum and C. frutescens are used to provide natural color and spicy taste of food. Allium cepa and A. sativum are usually processed by being ground up to a fine or thinly sliced then mixed with other spices such as Aleurites moluccanus and Anethum graveolens. However, A. sativum reported being used by local communities in Niger Delta, Nigeria as a seasoning and flavoring agent for the treatment of fever and chills (Ndukwu and Ben-Nwadibia 2005). 
Table 2. List of the spices and condiments plants and their utilization in the study area

\begin{tabular}{|c|c|c|c|c|c|c|}
\hline Scientific name & Family & $\begin{array}{l}\text { Vernacular } \\
\text { Name }\end{array}$ & Part used & Habit & Used & FI $(\%)$ \\
\hline Aleurites moluccanus (L.) Willd. & Euphorbiaceae & Kemiri & Fruit & Tree & Spices and condiment & 63,3 \\
\hline Allium сера $\mathrm{L}$ & Amaryllidaceae & Bawang mirah & Bulb & Herb & Spices and condiment & 100 \\
\hline Allium sativum $\mathrm{L}$ & Amaryllidaceae & Bawang puteh & Bulb & Herb & Spices and condiment & 100 \\
\hline Alpinia galanga (L.) Willd. & Zingiberaceae & Lengkues & Rhizome & Herb & Spices & 52 \\
\hline Amomum uliginosum J.Koenig & Zingiberaceae & Kapulage & Fruit & Herb & Spices & 59,33 \\
\hline Anethum graveolens $\mathrm{L}$ & Apiaceae & Adas & Seed & Herb & Spices & 50,67 \\
\hline Averrhoa bilimbi $\mathrm{L}$ & Oxalidaceae & $\begin{array}{l}\text { Asam belimbing, } \\
\text { Asam sunti }\end{array}$ & Fruit & Tree & Spices & 84 \\
\hline Capsicum аппиит $\mathrm{L}$ & Solanaceae & Cabe mirah & Fruit & Herb & Spices and condiment & 100 \\
\hline Capsicum frutescens $\mathrm{L}$ & Solanaceae & Cabe kecik & Fruit & Herb & Spices and condiment & 96 \\
\hline $\begin{array}{l}\text { Cinnamomum burmannii (Nees \& } \\
\text { T.Nees) Blume }\end{array}$ & Lauraceae & Kayu manih & Bark & Tree & Spices and condiment & 39,33 \\
\hline Citrus amblycarpa (Hassk.) Ochse & Rutaceae & $\begin{array}{l}\text { Jeruk } \\
\text { kunci/kesturi }\end{array}$ & Fruit & Tree & Spices & 18,67 \\
\hline $\begin{array}{l}\text { Citrus aurantifolia (Christm.) } \\
\text { Swingle }\end{array}$ & Rutaceae & Jeruk nipis & Fruit & Tree & Spices & 43,33 \\
\hline Citrus hystrix DC & Rutaceae & Jeruk purut & Fruit, leaves & Tree & Spices & 60,67 \\
\hline Cocos nucifera $\mathrm{L}$ & Arecaceae & Kelambe & Fruit & Tree & condiment & 68 \\
\hline Coriandrum sativum $\mathrm{L}$ & Apiaceae & Awas & Seed & Herb & Spices and condiment & 54,67 \\
\hline Cuminum cyminum $\mathrm{L}$ & Apiaceae & Jintan & Fruit & Herb & Spices and condiment & 48,67 \\
\hline Curcuma longa $\mathrm{L}$ & Zingiberaceae & Kunyik & $\begin{array}{l}\text { Rhizome, } \\
\text { leaves }\end{array}$ & Herb & Spices and condiment & 98 \\
\hline Cymbopogon citratus (DC.) Stapf & Poaceae & Sere dapur & Stem & Herb & Spices & 88 \\
\hline Etlingera elatior (Jack) R.M.Sm. & Zingiberaceae & Kecombrang & Flower & Herb & Spices & 35,33 \\
\hline Garcinia atroviridis Griffith et Anders. & Clusiaceae & Asam gelugur & Fruit & Tree & Spices & 55,33 \\
\hline Illicium verum Hook.f. & Schisandraceae & Pekak & Flower & Tree & Spices & 50,67 \\
\hline Murraya koenigii (L.) Spreng. & Rutaceae & Daun kare & Leaves & Tree & Spices & 98,67 \\
\hline Myristica fragrans Houtt. & Myristicaceae & Pale & Seed & Tree & Spices & 37,33 \\
\hline Ocimum $\times$ africanum Lour. & Lamiaceae & Kemangi & Leaves & Herb & Spices & 27,33 \\
\hline Paederia foetida $\mathrm{L}$ & Rubiaceae & Kentutan & Leaves & Climber & Spices & 24,67 \\
\hline Piper nigrum $\mathrm{L}$ & Piperaceae & Lade & Seed & Climber & Spices and condiment & 92,67 \\
\hline Premna serratifolia $\mathrm{L}$ & Lamiaceae & Bebuas & Leaves & Tree & Spices & 19,33 \\
\hline $\begin{array}{l}\text { Syzygium aromaticum (L.) Merr. \& } \\
\text { L.M.Perry }\end{array}$ & Myrtaceae & Cengkeh & Flower & Tree & Spices & 36 \\
\hline $\begin{array}{l}\text { Syzygium polyanthum (Wight) } \\
\text { Walp. }\end{array}$ & Myrtaceae & Salam & Leaves & Tree & Spices & 86 \\
\hline Tamarindus indica $\mathrm{L}$ & Fabaceae & Asam jawe & Fruit & Tree & Spices & 68 \\
\hline Zingiber officinale Roscoe & Zingiberaceae & Halie & Rhizome & Herb & Spices and condiment & 90 \\
\hline
\end{tabular}

Tabel 3. Category of spices and condiment plants

\begin{tabular}{ll}
\hline Category & Species \\
\hline Flavoring & Aleurites moluccanus, Allium cepa, A. sativum, Alpinia galanga, Amomum uliginosum, Anethum graveolens, \\
& Averrhoa bilimbi, Capsicum annum, C. frutescens, Cinnamomum burmannii, Citrus amblycarpa, C. \\
& aurantifolia, C. hystrix, Cocos nucifera, Coriandrum sativum, Cuminum cyminum, Curcuma longa, \\
& Cymbopogon citratus, Etlingera elatior, Garcinia xanthochymus, Illicium verum, Murraya koenigii, Myristica \\
& fragrans, Ocimum $\times$ africanum, Paedera foetida, Piper nigrum, Premna serratifolia, Syzygium aromaticum, S. \\
& polyanthum, Tamarindus indica, Zingiber officinale \\
Seasoning & Aleurites moluccanus, Allium cepa, A. sativum, Alpinia galanga, Amomum uliginosum, Anethum graveolens, \\
& Capsicum annuum, C. frutescens, Cinnamomum burmannii, Citrus amblycarpa, C. aurantifolia, C. Hystrix, \\
& Coriandrum sativum, Cuminum cyminum, Curcuma longa, Cymbopogon citratus, Garcinia xanthochymus, \\
& Illicium verum, Murraya koenigii, Myristica fragrans, Ocimum $\times$ africanum, Piper nigrum, Syzygium \\
& aromaticum, S. polyanthum, Tamarindus indica, Zingiber officinale \\
Colouring & Capsicum annuum, Curcuma longa \\
Preservation & Averrhoa bilimbi, Garcinia xanthochymus, Tamarindus indica \\
\hline
\end{tabular}


Table 4. Trade of spice and condiment plants

\begin{tabular}{|c|c|c|c|c|}
\hline \multirow[b]{2}{*}{ Scientific name } & \multirow[b]{2}{*}{ Trade part } & \multirow{2}{*}{$\begin{array}{l}\text { Number of } \\
\text { respondents }\end{array}$} & \multicolumn{2}{|c|}{ Marketing } \\
\hline & & & $\begin{array}{l}\text { Mean quantity marketed per } \\
\text { respondent }(\mathrm{kg})\end{array}$ & Market price (IDR/kg) \\
\hline Allium сера & Bulb & 3 & $120 \pm 1.25$ & 50.000 \\
\hline Allium sativum & Bulb & 2 & $80 \pm 0.94$ & 15.000 \\
\hline Alpinia galanga & Rhizome & 3 & $8 \pm 0.67$ & 5.000 \\
\hline Averrhoa bilimbi & Fruit & 1 & $20 \pm 1.25$ & 10.000 \\
\hline Capsicum аппиит & Fruit & 5 & $20 \pm 0.94$ & 20.000 \\
\hline Capsicum frutescens & Fruit & 4 & $25 \pm 2.36$ & 50.000 \\
\hline Citrus aurantifolia & Fruit & 2 & $7 \pm 1.33$ & 10.000 \\
\hline \multirow[t]{2}{*}{ Citrus hystrix } & Fruit & 3 & $7 \pm 1.33$ & 30.000 \\
\hline & Leaves & 3 & $2 \pm 0.75$ & 10.000 \\
\hline \multirow[t]{2}{*}{ Cocos nucifera } & Old fruit & 50 & $200 \pm 6.67$ & 1.750 \\
\hline & Young fruit & 50 & $100 \pm 4.19$ & 3.000 \\
\hline \multirow[t]{2}{*}{ Curcuma longa } & Rhizome & 4 & $5 \pm 0.94$ & 5.000 \\
\hline & Leaves & 4 & $1 \pm 0.3$ & 50.000 \\
\hline Cymbopogon citratus & Stem & 6 & $8 \pm 1.41$ & 3.000 \\
\hline \multirow[t]{2}{*}{ Garcinia atroviridis } & Dried fruit & 3 & $20 \pm 2.31$ & 6.000 \\
\hline & Wet fruit & 3 & $300 \pm 2.49$ & 2.000 \\
\hline
\end{tabular}

Several leaves of spices plants such as Syzygium polyanthum and Citrus hystrix are often used as a natural flavoring. These plants have essential oil content that provide a distinctive fragrance (Cahyadi 2006; Apriliani 2014). However, Paedera foetida and Premna serratifolia are very important condiments to making bubur pedas. These plants provide a distinctive taste and aroma. Spices that contain essential oils and are used by the community as natural flavorings are safe to use because they belong to the GRAS (Generally Recognized as Safe) group (Kim et al. 1995). P. foetida leaves also have benefits as a traditional medicine to treat digestive problems (Noprianti et al. 2018). Averrhoa bilimbi, Tamarindus indica, and Garcinia xanthochymus fruit can be used as a food additive for improving the aroma, taste, and food preservatives (Aqilah 2017).

\section{The production and marketing of spice and condiment plants}

Most of the respondents produced spices and condiment plants primarily for household consumption. Women and children were responsible for growing and selling the fresh produce of spices and condiment plants. Most of these plants are planting in the home garden. Approximately 57 $\%$ of the respondents have sold spices and condiment plants to increase household income. The widely produced home garden spices and condiments in the study area for both house consumption and sold in the local market were A. galanga, A. bilimbi, C. longa, and G. atroviridis (Table 4).

Most of the respondents sold spices and condiments to intermediary traders, some to consumers. The head of the household was responsible for selling spices and condiments in traditional markets. However, women usually sell small amounts of spices and condiment plants on the markets to meet basic needs, such as salt or eggs similar to the report of in South-West Ethiopia (Agize et al.
2013; Agize 2016) and in West Kalimantan (Robi et al. 2019). Generally, spices have been sold freshly, but several species have been dried, such as $G$. atroviridis before being sold, as is the case with the North Aceh people Indonesia (Navia et al. 2019b). The mean total annual contribution to the income of the household of the spices and condiment plants was around $38 \%$. From all respondents selling spices and condiment plants, $72 \%$ were found to be earning annually less than 15,000,000 Indonesian Rupiah (IDR), $25 \%$ earned between IDR 16.000,000 and IDR $30,000,000$ while the remaining households earned more than IDR 30,000,000 but less than IDR 80,000,000.

Capsicum annuum were also commonly found in the study area as a similar report from in the Niger Delta Area of Nigeria (Ndukwu and Ben-Nwadibia 2005) and in Indonesia (Djarwaningsih 2005; Robi et al. 2019) and have high economic value. Indonesia was also one of the world's leading exporting countries in 2013, with the HS 904 group (Pepper, Chile, and Capsicum) among them (Hermawan 2015). This species widely consumed directly as vegetables or processed as spices in dried forms and also a primary ingredient in various hot sauces and pastes in different cuisines in Aceh Tamiang. The unique pungent flavor of $C$. annuum is due to the content of capsaicin and dihydrocapsaicin (Wang et al. 2009) which may increase appetite. The $C$. annuum was almost found in every home garden and the farmlands. Spices were sold separately or in various mixtures. Most of the traditional markets in Aceh Tamiang have been exceptionally well provided with indigenous and imported spices at all periods of the year.

\section{Transfer of traditional knowledge among Tamiang Tribe}

Culture plays a critical role in rural tribal livelihood, especially for the use of various spice and condiments plants (Bharali et al. 2017; Navia at al. 2019a). Each traditional cuisine has a special flavor that makes the taste 
of the cuisine unique. Seventeen species used for made bubur pedas, 5 species for Anyang, and 7 species for making Ikan Cang Rebong. However, Ikan Cang Rebong can be processed into two versions, namely sayur lemak and pepes. Traditional knowledge of the Tamiang tribe in the preparation and making of traditional cuisine has been passed down from generation to generation. Respondents from the study explained that knowledge of spices and condiments plants has been acquired mostly from parents and grandparents depicts that parents and grandparents account for $38 \%$ of knowledge, while $23 \%$ is mainly ancestors. Mothers always involve their daughters in the preparation and making of traditional cuisine. This study consistent with reported by Aqilah (2017) in Babah Dua Village, Aceh Jaya District, Aceh, Indonesia and in Kopen Dukuh Village, Banyuwangi District, East Java, Indonesia (Hakim et al. 2015). Van der Hoeven et al. (2013) reported elders to be the custodians of knowledge and transfer it to ensure it is not lost through generations. The study has recorded elders to be more knowledgeable about spices and condiment plants. In support of the study van der Hoeven et al. (2013) states that elders are the custodians of knowledge and they transfer their knowledge with such confidence so that it will not be lost through generations. Transfer of indigenous information within communities was mainly from parents to the younger generation (Ahmad and Pieroni 2016). The Tamiang tribe has always preserved traditional knowledge of the use of various spices and condiment plants for traditional cuisine.

\section{ACKNOWLEDGEMENTS}

We are grateful to all people in the studied villages for their kind hospitality and share of knowledge. We are also grateful that the University of Samudra, Aceh, Indonesia has supported this study.

\section{REFERENCES}

Achinewu SC, Aniena MI, Obomanu FG. 1995. Studies on spices of food value in the South eastern states of Nigeria 1: Antioxidants properties. J Afr Med Plants 18: 135-139.

Agize M, Demissew S, Asfaw Z. 2013. Indigenous knowledge on management of home gardens and plants in Loma and Gena Bosa Districts (Weredas) of Dawuro Zone, Southern Ethiopia: Plant biodiversity conservation, sustainable utilization and environmental protection. Intl J Sci: Basic Appl Res 10 (1): 63-99.

Agize M. 2014. Ethnobotany of spice and condiment plants and the associated indigenous knowledge on management, utilization and conservation of them in and around home gardens in Loma and Gena Bosa Districts (Weredas) of Dawuro Zone, Southern Ethiopia. Intl J Agric Innov Res 4 (3): 426-442.

Agize M. 2016. Spice and medicinal plants production and value chain analysis from South-West Ethiopia. J Pharm Altern Med 10: 126-144.

Ahmad K, Pieroni A. 2016. Folk knowledge of wild food plants among the tribal communities of Thakhte-Sulaiman Hills, North-West Pakistan. J Ethnobiol Ethnomed 12: 1-15.

Apriliani A, Sukarsa, Hidayah HA. 2014. Study of plant ethnobotany as a food additive traditionally by the community in the Sub-district of Pekuncen, Banyumas District. Scripta Biologica 1 (1): 76-84.

Aqilah CS. 2017. Ethnoecology and ethnobotany of spice plants Aceh community. [Thesis]. Bogor Agricultural University, Bogor. [Indonesian]
Arif A, Suwarna B, Gentong AW. 2013 Maret 31. Tales of trade and war in Aceh Curry. Kompas, Archipelago Culinary Exploration Rubric, Maret 31, 2013, 33-36. [Indonesian]

Bharali P, Sharma M, Sharma CL, Singh B. 2017. Ethnobotanical survey of spices and condiments used by some tribes of Arunachal Pradesh. J Med Plants Stud 5 (1): 101-109.

Cahyadi S. 2006. Analysis and Health Aspects of Food Additives. First Edition. PT Bumi Aksara, Jakarta. [Indonesian]

Chakraborty S, Chaturvedi HP. 2015. Some wild edible genetic resources of vegetables andspices of Tripura. Indian Res J Genet Biotechnol 7 (1): 132-137

Djarwaningsih T. 2005. Capsicum spp. (chilli): Origin, distribution, and its economical value. Biodiversitas 6 (4): 292-296

Elfrida, Mubarak A, Suwardi AB. 2020. The fruit plant species diversity in the home gardens and their contribution to the livelihood of communities in rural area. Biodiversitas 21 (8): 3670-3675.

Gadegbeku C, Tuffour MF, Katsekpor P, Atsu B. 2014. Herbs, spices, seasonings and condiments used by food vendors in Madina, Accra. Caribb J Sci Technol 2: 589-602.

Gudade BA, Babu S, Deka TN, Vijayan AK, Chhetri P. 2015. Spices biodiversity and their ethnomedicinal uses by tribal community of Sikkim, India. Vegetos 28 (1): 141-145

Hakim L. 2015. Spices and Herbs of Community Home Gardens: Diversity, phytopharmaca Sources and Health-fitness Tourism. Diandra Creative, Yogyakarta. [Indonesian]

Hakim L, Batoro J, Sukenti K. 2015. Ethnobotany spices in the Kopen Dukuh Village of Banyuwangi District. Jurnal Pembangunan dan Alam Lestari 6 (2): 133-142. [Indonesian]

Hermawan I. 2015. The competitiveness level of Indonesian spices in ASEAN market before and after global economic crisis. Buletin Ilmiah Litbang Perdagangan 9 (2): 153-178. [Indonesian]

Hidayati MD, Ersam T, Shimizu K, Fatmawati S. 2017. Antioxidant activity of Syzygium polynthum extracts. Indon J Chem 17 (1): 49-53.

Ismail A, Ahmad WANW. 2019. Syzygium polyanthum (Wight) Walp: A Potential Phytomedicine. Pharm J 11 (2): 429-438.

Kim JM, Marshall MR, Wei CI. 1995. Antibacterial activiti of some esential oil components against five foodborne pathogen. J Agric Food Chem 43 (11): 2839-2845.

Kumar N, Singh AK. 2014. Plant profile phytochemistry and pharmacology of Avartani (Helicteres isora Linn.): A review. Asian Pac J Trop Biomed 4 (1): 22-26.

Kumar P, Singh V, Singh A. 2014. Ethnobotanical studies of plant species associated with Hippophae sp. in Chandra Valley a part of cold desert biosphere reserve Himachal Pradesh, India. Ann Plant Sci 3 (7): 754757.

Madikizela B, Ndhlala AR, Finnie JF, Van Staden J. 2012. Ethnopharmacological study of plants from Pondoland used against diarrhoea. J Ethnopharmacol 141: 61-71.

Maheshwari S, Tomar SS, Sharma A. 2018. A study of ethnobotanical knowledge of tribal plants: a review of decade. Intl J Adv Sci Res Manag 1: 2455-6378.

Mahwasane ST, Middleton L, Boaduo N. 2013. An ethnobotanical survey of indigenous knowledge on medicinal plants used by the traditional healers of the Lwamondo area, Limpopo province, South Africa. S Afr J Bot 88: 69-75.

Manangka CA, Linda R, Mukarlina. 2017. Utilization of plants as natural flavors by the Kanayatn Dayak Tribe, Sebatih Village, Sengah Temila Sub-district, Landak District. Protobiont 6 (3): 158-164.

Manoj P, Soniya EV, Banerjee NS, Ravichandran P. 2004. Recent studies on well-known spice, Piper longum Linn. Nat Prod Radiance 3 (4): 222-227.

Mulu M, Ntelok ZRE, Sii P, Mulu H. 2020. Ethnobotanical knowledge and conservation practices of indigenous people of Mbeliling Forest Area, Indonesia. Biodiversitas 21(5): 2085-4722.

Navia ZI, Chikmawati T. 2015. Durio tanjungpurensis (Malvaceae), a new species and its one new variety from West Kalimantan, Indonesia. Bangladesh J Bot 44 (3): 429-436.

Navia ZI, Suwardi AB, Saputri A. 2019a. Characterization of local fruits in the Leuser Ecosystem of Aceh Taming District, Aceh. Buletin Plasma Nutfah 25 (2): 133-142. [Indonesian]

Navia ZI, Suwardi AB, Nuraini, Seprianto. 2019b. Ethnobotany of wild edible fruit species and their contribution to food security in the North Aceh Region, Indonesia. Intl Conf ASEAN 2019: 203-210. DOI: $10.1515 / 9783110678666-027$

Navia ZI, Suwardi AB, Harmawan T, Syamsuardi, Mukhtar E. 2020. The diversity and contribution of indigenous edible fruit plants to the rural 
community in the Gayo Highlands, Indonesia. J Agric Rural Dev Trop Subtrop 121 (1): 89-98.

Ndukwu BC, Ben-Nwadibia NB. 2005. Ethnomedicinal aspects of plants used as spices and condiments in the Niger Delta area of Nigeria. Ethnobot Leaflets 2005: 10.

Noprianti D, Nugroho RA, Sudiastuti. 2018. Effect of healed leaf water extract (Paederia foetida Linn.) on morphometry and survival of mice fetus (Mus musculus L.). Jurnal Biota 4 (2): 49-53. [Indonesian]

Rathore MS, Shekhawat NS. 2008. Incredible spices of India: from traditions to cuisine. Am-Eurasian J Bot 1 (3): 85-89.

Robi Y, Kartikawati SM, Muflihati. 2019. Traditional Ethnobotany of Spices in the Village of Empoto, Sanggau District, West Kalimantan. Jurnal Hutan Lestari 7 (1): 130-142. [Indonesian]

Salam S, Jamir NS. 2016. Common spices plant used as medicine by the Tangkhul tribe of Ukhrul District, Manipur, India. Intl J Sci Res Publ 6 (7): $22-25$

Sarangnga Y, Suaib, Wijayanto T. 2013. Morphological characterization of gingers (Zingiberaceae) in the Katangana River Basin of South Tiworo. Berkala Penelitian Agronomi 2 (2): 87-93. [Indonesian]

Shrestha PM, Dhillion SS. 2006. Diversity and traditional knowledge concerning wild food species in a locally managed forest in Nepal. Agrofor Syst 66: 55-63.

Supiandi MI, Mahanal S, Zubaidah S, Julung H, Ege B. 2019. Ethnobotany of traditional medicinal plants used by Dayak Desa Community in Sintang, West Kalimantan, Indonesia. Biodiversitas 20: $1264-1270$

Suryadarma IGP. 2010. Diversity of plants of fitness material in the lontar rukmini tatwa manuscript of Balinese society. Biota 15 (2): 294-305

Suwardi AB, Indriaty, Navia ZI. 2018. Nutritional evaluation of some wild edible tuberous plants as an alternative foods. Innovare J Food Sci 6 (2): 9-12.
Suwardi AB, Navia ZI, Harmawan T, Syamsuardi, Mukhtar E. 2019. The diversity of wild edible fruit plants and traditional knowledge in West Aceh region. Indonesia. J Med Plants 7 (4): 285-290.

Suwardi AB, Navia ZI, Harmawan T, Nuraini, Syamsuardi, Mukhtar E. 2020a. Ethnobotany, nutritional composition and sensory evaluation of Garcinia from Aceh, Indonesia. Mater Sci Eng 725 (1): 012064.

Suwardi AB, Navia ZI, Harmawan T, Syamsuardi, Mukhtar E. 2020 b. Ethnobotany and conservation of indigenous edible fruit plants in South Aceh, Indonesia. Biodiversitas 21 (5): 1850-1860.

Suwardi AB, Navia ZI, Harmawan T, Syamsuardi, Mukhtar E. 2020c. Wild edible fruits generate substantial income for local people of the Gunung Leuser National Park, Aceh Tamiang Region. Ethnobot Res Appl 20: 1-13.

Tamin R dan Arbain D, 1995. Biodiversity and Ethnobotany Survey. Workshop paper on Insulation of Efficacious Compounds. Cooperation of HEDS-F MIPA Andalas University, Padang. [Indonesian]

The Central Bureau of Statistics of Aceh Tamiang District. 2020 Tenggulun Sub-district in figure 2019. The Central Bureau of Statistics of Aceh Tengah District, Aceh Tamiang District, Indonesia. [Indonesian]

Van der Hoeven M, Osei J, Greeff M, Kruger A, Faber M, Smuts CM. 2013. Indigenous and traditional plants: South African parents' knowledge, perceptions and uses and their children's sensory acceptance. J Ethnobiol Ethnomed 9: 78. DOI: 10.1186/1746-4269978.

Wang Y, Xia Y, Wang J, Luo F, Huang Y. 2009. Capsaicinoids in chili pepper (Capsicum annuum L.) powder as affected by heating and storage methods. Am Soc Agric Biol Eng 52 (6): 2007-2010. 